\title{
The Effect of Modernisation on Acquisition of Property and the Rules of Compensation - A Kenyan Case
}

\author{
By R.S. Bhalla
}

Acquisition is a primary instinct of man. In early times individual ownership of private property was essentially customary. Its recognition as a legal right is affirmed in the Constitution of Kenya which establishes the right of property and alludes to its social functions. The Constitution provides that the state can impose restrictions on the enjoyment and use of property in certain circumstances. More so, if necessary it can even deprive a person of his private property, by vesting the title in the state itself, in the wider interest of the community, and paying him compensation. This essay is restricted to this aspect of compensation. It examines the rules relating to compensation, as provided under the Land Acquisition Act, Cap. 295. This is an important area of the social and economic well being of an individual since acquisition, in whatever form, is always considered an intrusion upon private property. It is a breach of the sanctity of private property. No matter how extravagant the compensation paid, the mental trauma of mine and thine, the satisfaction in one's belongings can never be assessed in terms of money. In fact, compensation can never compensate the owner because of his esteem and reverence for his property; his whole life grinds around it. Nevertheless, the life of the community, its welfare, its needs, its development and progress demand a sacrifice of the individual's interest. The community, however, tries to compensate this sacrifice in terms of money value. Compensation based upon market value is usually cited to achieve this objective. However, such a basis of compensation breaks down when the property compulsorily acquired commands no market value but is nevertheless of substantial value to the owner; for example, a private place of worship for a special type of worship. Again, market value, as a basis of compensation, is only partially effective in restoring the owner's financial position when the property has been especially adapted to the proprietor's convenience in a manner that does not add significance to market value. The main stress in this essay is not on the justification for acquisition of private property in the public interest, but on the need to compensate the individual to the nearest point of his self-satisfaction.

\section{Acquisition of Private Property}

There will never come a time when ownership of private property of some kind will ever cease. At the same time there will never be a notion of property which gives an individual 
an absolute right or "sole despotic dominion". ${ }^{1}$ Thus under the Constitution of Kenya the right of property is left unaffected by section 83(1) which allows derogation from fundamental rights under the Preservation of Public Security Act. It does not mean that the right of property is regarded as absolute. There are two possible reasons for this deliberate omission. First, the right of property 2 , like all other fundamental rights guaranteed under Chapter 5 of the Constitution, is subject to restrictions under normal circumstances in the general public interest. Second, while a person can be deprived of his property in the public interest and paid compensation even under normal circumstances, there cannot, possibly, be a further derogation of the right of property under any circumstances. Therefore, in case of the right of property all interferences with the right of property, whether under normal circumstances or under special circumstances cannot imply any further derogation - than depriving one of one's property. But as far as other fundamental rights are concerned, there can be a near absolute or absolute derogation only under special circumstances. For example, the right to life is subject to restrictions even under normal circumstances since no right can command supremacy even under normal circumstances over the public interest. But a special derogation can only be under special circumstances when a person is to be subject to unusual restrictions. That seems to be why the right of property is left unaffected by Section 83(1).

There is nothing anti-social or anti-property in the notion of property discussed above. The existence of these two ideas, namely the everlasting nature of the right of property and the absence of absolute character in the right of property, is essential to the continued existence of the state and the society. These ideas are inherent in the sovereign power of the state, formulated in the doctrine of eminent domain, an offspring of political necessity. Sovereign government has a power to acquire the private property of its people under its protection for public use irrespective of the wishes of the owner. This power, therefore, presupposes the existence of property and nullifies its absolute character. Public use is a pre-condition to the exercise of this power. Although the right of compensation does not follow from the doctrine of eminent domain, it is always accepted 3 that the payment of compensation is an essential ingredient in the valid exercise of this power. It is in this sense that the notion of property is enshrined in the constitution - that the material resources of the community must be used to serve the best interest of the community.

The problem of reconciling the idea of private property with social well being is engaging attention all over the world. The task of adjusting the old institution of property to the harmonious relationship with new social forces is a vexed question. It is the adjustment of an old concept to new changing circumstances. Such an adjustment, in the constitution of

1 Blackstone, 2 Commentaries on the Laws of England 1-2 (1830).

2 2. Section 75.

3 Section 75(1)(c). All sections referred herein refer to the Constitution of Kenya. 
Kenya, is achieved through two methods: first, by imposing restrictions in normal circumstances for the promotion of public interest; and second, by widening these restrictions to deal with a special social melange in the preservation of social order. But under no circumstances can a proper equilibrium be achieved between individual rights and social interests. Efforts in quest of some equilibrium are to be found under Section 75 of the Constitution. 4 Prima facie, govemment is the judge of the existence of the public interest, even though it is not the absolute judge. 5 The question is a judicial one because "every person having an interest or right in or over property which is compulsorily taken possession of or whose interest in or right over any property is compulsorily acquired shall have a right of direct access to the High Court for ... the determination of ... the legality of the taking of possession or acquisition of the property, interest or right". 6 For a judicial process it will pose a subtle question of finding a balance between an individual's interest and the interest of the community. The courts, in fact, do not interfere with the govermment determination of public interest except to enquire whether the legislature could have reasonably considered the possiblity of a public use, and they attach great respect to the legislative declaration as to public use. 7

It is the social control of property that brings into context the compulsory acquisition and payment of compensation. Social control of property is exercised in many ways - by putting restrictions on the use of property 8 and by compulsory acquisition. 9 However, one can also argue that the reconciliation of private interest in property with the public interest is not a problem, since property is a social concept. For example Ihering states:

The only reason that the demands of the society are not so evident in property is the circumstance that the proprietor's own interest determines him as a rule to use his property in such a way as will further the interest of society along with his own. 10

Compulsory acquisition is a form of social control though one can say that it is an extreme form of social control quite different from putting restrictions on the use and enjoyment of property. By stressing these forms of social control, it is evident that the natural unit of economic activity is no longer an individual but the entire community. This method of specific adjustment of private property to social needs can also be looked at from the point of view of deliberate rational and equitable control and distribution of property through the

4 In fact, such an approach is made in all other fundamental rights guaranteed under Chapter 5 of the Constitution.

5 Destro v. The Attomey-General [1980] K.L.R. 80.

6 Section 75(2)(a).

7 Supranote 5.

8 Haridas Chhagan Lal v. Kericho U.D.C. [1965] E.A. 370.

9 Supra note 5.

$10 R$. von Ihering, Law as a Means to an End, trans. by I. Husik 406 (1968). 
agency of the state. It is against this background that the idea of acquisition of property should be understood, as enshrined in the Constitution of Kenya. Under the Constitution the enchroachments on the right of property are made in the public interest.

Since any enchroachment or interference is made only in the public interest, it can be regarded as fulfilment of the social function of property. It is an imposition of obligations on the owner, that his possessions are for social needs. Such an idea puts an end to all known and imagined abuses of property to the disadvantage of society. The same law which creates property also assigns it a social function. It is within the sphere of law that the various aspects of property are regulated. Under the Constitution the only condition to the state's control is that the law must be a valid law. 11 Property, therefore, is a creation of law12; it is a system of legal rights and duties relating to extemal objects which have economic value.

Section 75 refers to property of any descriptions. It shows that the term property is used in a comprehensive sense to include both corporeal and incorporeal, movable and immovable, tangible and intangible forms of property which have economic value. It includes all those things that can be appropriated and enjoyed. It also refers to the legal sense of a bundle of rights to include modem types of the forms of property which can be enjoyed to the exclusion of all others. In case of interference with property interest or right, the Constitution allows for compulsory taking of possession, and compulsory acquisition, of property. The term "taking possession of" suggests the idea of taking physical possession which is generally understood in traditional agricultural economies. Properties such as land, house etc. which are immovable properties can only be held by taking actual physical possession or control. The term "acquisition" refers to the welldeveloped modern economic interests and rights such as patens, shares, etc. which, at a proper terminological level, can only be acquired since there is no physical possession involved in their acquisition. Thus the question of compulsory taking of possession and compulsory acquisition takes care of both types of property, corporeal and incorporeal, movable and immovable. It covers property both in the traditional sense, that refers to agricultural societies, and modern technical societies which have found new methodes of controlling resources of wealth. It is in the light of the complexity of tradition and modemity that the concept of property is understood and entrenched in the Constitution of Kenya.13 The incorporation of such modem developments in the basic law is essential and beneficial to a proper modem economic development.

11 Section 3.

12 Bentham, Theory of Legislation 113 (1904).

13 Section $75(1)$. 
Prior to the enactment of the Constitution, there was no guarantee against any law affecting the right of property. Property relations were regulated by the ordinary law of the land. When Kenya attained her independence from Britain in 1963 and subsequently became a sovereign Republic, the founding fathers with the background of foreign domination and exploitation secured the right of property against ordinary law enchroachments by instituting the right of property in the Constitution as a fundamental right. This gives the right of property an additional protection against ordinary-law enchroachments. But so far as the question of compulsory acquisition of private property in the public interest on the payment of compensation is concerned, the Constitution has brought no marked change. The Land Acquisition Act, 1894 provided for compulsory acquisition of property on payment of compensation. So this aspect of the law was well known before Kenya became a sovereign Republic.

All restrictions, whether amounting to total deprivation or falling short of it, can only be imposed in the general interest of the society. 14 Therefore, no property interest or right can be interfered with, without a consideration of public interest, even if compensation is paid. Otherwise, this will amount to confiscation, and the Constitution does not allow confiscation. If section 75(1)(a) is deleted it will write off public purpose and allow the state to take private property at will by paying compensation. In such a situation purpose becomes unquestionable in the court of law. Public purpose is interpreted in B.P. Bhatt and Another v. Habib Versi Bajani15 as public interest referring to the aims and objectives in which the general interest of the community, as opposed to the particular interest of individuals, is directly and vitally concerned, such as highway improvements. 16 Public purpose does not include proping up the financial position of one person at the cost of another by the state. The idea is not to take from the rich and give to the poor, to establish economic equality. Willoughby states:

As between individuals, no necessity, however great, no exigency, however imminent, no improvement, however valuable, no refusal, however unneighbourly, no obstinacy, however unreasonable, no offer of compensation, however extravagant, can compel or require any man to part with an inch of his estate.17

14 Section 75(1) (a-b).

15 [1958] E.A. 536.

16 Collector v. Heptulla and Others [1968] E.A. 555 at 556.

17 Willoughby, 2 The Constitutional Law of the United States 759 (1929). 


\section{Critical Aspect of the Rules of Compensation under the Land Acquisition Act. (Cap. 295)}

The Constitution, under Section 75, provides for compulsory acquisition of private property. Compulsory acquisition is subject to payment of compensation, 18 and compensation to be paid is "full payment".19 Again, under Section 85(2)(a) the owner has the right to contest the amount of money paid in compensation. Since both these sub-sections deal with compensation, they are inclusive. The owner can challenge both the amount of compensation and the manner or procedure followed in arriving at that amount. The Constitution provides for full compensation which simply means the price that would be agreed between a willing seller and a willing purchaser, that is, the price which the property would fetch in the open market. In New Munyu Sisal Estate Ltd. v. The Attorney-General20 the court held that arbitrary or artificial compensation cannot be regarded as compensation within the meaning of Section 75(1)(c). Compensation means fair amount according to market practice, business principles and trade practices. Therefore, if the rules provided to calculate the amount of compensation do not lead to full compensation, it is the duty of the court to declare the rules null and void.21 If the rules are deficient on elements which are to be taken into consideration in calculating the amount of compensation, it needs legislative action to amend these rules. In fact from both these arguments it is evident that the amount of compensation itself is only an ancillary concem of the court since it is not an evidence of the market value or a fair compensation. The real concern of the court is with the procedure used to arrive at the amount of compensation. It is this procedure that is the concem in this part of the essay.

There is a long list of cases 22 which define compensation in terms of market value. Before the constitution came into force in 1963, the Land Acquisition Act, 1894 referred to compensation in terms of market value. 23 The concept of market value is itself uncertain

18 Section 75(1)(c).

19 Ibid.

20 [1972] E.A. 77. In India, in West Bengal v. Mrs. Bella Bannerjee', the court said: While it is true that the legislature is given the discretionary power of laying the principles which should govem the determination of the amount to be given to the owner for the property appropriated, such principles must ensure that what is determined as payable must be compensation, that is, a just equivalent of what the owner has been deprived of. Whether such principles take into account all the elements which make up the true value of the property appropriated and include matters which have been neglected is a justiciable issue to be adjudicated by the court. A.I.R. 1954 S.C. 176.

21 Section 3.

22 New Munyu Sisal Estates Ltd. v. A.G. [1972] E.A. 88. Institute of the Blessed Virgin Mary, Kenya (registered Trustees) v. The Commissioner of Lands [1980] K.L.R. 5.

23 The Land Acquisition Act, 1894 and the Land Acquisition Act, Cap. 295 which came into force on 23 Aug. 1968 are similar in measure of compensation. But the question of prompt and full 
since valuation is not an exact science. It is a specialised art that needs rules for guidance to arrive at the market value. With widespread and frequent use of government powers in acquiring private property under circumstances stated in Section 75(1)(a), it is essential that the adjudicators are to be provided with rules to calculate market value. To remove this uncertainty, a clear-cut guidance is provided for calculating market value, under the Land Acquisition Act (Cap. 295).24 The Act states what factors are to be taken into consideration and what factors are to be ignored in assessing the value of a compulsorily acquired property.

The modern techniques of planning have so advanced that their influence in assessing the market value of the property cannot be ignored. The planning processes form part of the valuation techniques. 25 For example, planning permissions and planning restrictions 26 are used in assessing the increase and decrease in the value of the property in the open market. Even the nature of planning permission affects the value of the property. For example, where a planning authority has granted a planning permission on personal grounds, that permission is limited only to the applicant; these permissions are ignored in assessing value because they are not attached to the property. These days land is rarely sold in the open market until the planning permission has been established. When the property is compulsorily acquired, it is withdrawn from the market, under a special development scheme. How this special development scheme affects valuation is an important question although the use to which the compulsorily acquired property is put afterwards may well have no commercial counterpart. The Land Acquisition Act, (Cap. 295) provides guidance on these matters. Armed with these rules, the valuers are to consider what the land would fetch on the open market.

The basic principle of the law of compensation is that the sum swarded should as far as practicable place the claimant in the same financial position as he would have been in had there been no question of his property being compulsorily acquired. The compensation will fall to be assessed on the basis of full market value. However, before being involved in details, it is useful to set out the rules dealing with compensation for compulsorily purchased property. The rules are laid down under the Land Acquisition Act (Cap. 295). Although the rules deal with compulsorily acquired land, their application in case of general acquisition of property is also applicable. These rules are27:

compensation is not mentioned in the Land Acquisition Act. 1894. The Land Acquisition Act, Cap. 295 in Sections 6(1), 8 and 29(1) use wordings similar to Section 75(1)(c) of the Constitution.

24 See schedule.

25 Destro and Others v. The Attomey-General [1980] K.L.R. 77. The Collector v. Heptulla and Others [1968] E.A. 555.

26 Institute of the Blessed Virgin Mary, Kenya (Registered Trustees) v. The Commissioner of Lands [1980] K.L.R. 5.

27 The Land Acquisition Act, Cap. 295, Schedule. 
1. (1) For the purposes of this schedule, "market value" in relation to land means the market value of the land at the date of publication in the Gazette of the notice of intention to acquire the land.

(2) In assessing the market value, the effect of any express or implied condition of title or law which restricts the use to which the land concerned may be put shall be taken into account.

(3) If the market value of land has been increased, or is currently increased, in either of the following ways, the increase shall be disregarded -

(a) an increase by reason of an improvement made by the owner or his predecessor in title within two years before the date of publication in the gazette of the notice of intention to acquire the land, unless it is proved that the improvement was made bona fide and not in contemplation of proceedings for the acquisition of the land;

(b) an increase by reason of the use of the land or premises thereon in a manner which could be restrained by a court or is contrary to the law, or is detrimental to the health of the occupiers of the premises or to the public health.

2. In determining the amount of compensation to be awarded for land acquired under this Act, the following matters, and no others, shall be taken into consideration -

(a) the market value as determined in accordance with paragraph 1;

(b) damage sustained or likely to be sustained by persons interested at the time of the commissioner's taking possession of the land by reason of severing the land from his other land;

(c) damage sustained or likely to be sustained by persons interested at the time of the Commissioner's taking possession of the land by reason of the acquisition injuriously affecting his other property, whether movable or immovable, in any other manner or his actual earnings;

(d) if, in consequences of the acquisition, any of the persons interested is or will be compelled to change his residence or place of business, reasonable expenses incidental to the change; 
(e) damage genuinely resulting from diminution of the profits of the land between the date of publication in the Gazette of the notice of intention to acquire the land and the date the Commissioner takes possession of the land.

3. In determining the amount of compensation to be awarded for land acquired under this Act, the following matters shall not be taken into consideration -

(a) the degree of urgency which has led to the acquisition

(b) any disinclination of the person interested to part with the land;

(c) damage sustained by the person interested which, if caused by a private person, would not be a good cause of action;

(d) damage which is likely to be caused to the land after the date of publication in the Gazette of the notice of intention to acquire the land or in consequence of the use to which the land will be put;

(e) any increase in the value of the land likely to accrue from the use to which it will be put when acquired;

(f) any outlay on additions or improvements to the land, incurred after the date of publication in the Gazette of the notice of intention to acquire the land, unless the additions or improvements were necessary for the maintenance of any building in a proper state of repair.

4. To the amount of compensation so determined there shall be added a sum equal to fifteen per cent of the market value as determined in accordance with paragraph 1 , by way of compensation for disturbance.

5. Where, at any inquiry made by the Commissioner under Section 9, a person interested has:

(a) claimed compensation for any land or any interest therein, that person shall not at any time be awarded an amount beyond the amount claimed;

(b) refused, or omitted without sufficient reason to be allowed by the Court, to make a claim for compensation, that person shall not at any time be awarded an amount beyond the amount awarded by the Commissioner. 
Under Section 3(e) of the Schedule 28 "any increase in the value of the land likely to accrue from the use to which it will be put when acquired" is to be ignored in computing compensation.

The effect of development schemes is a latent effect. Unless they are fully executed, it is difficult to see how they will affect the price structure of other properties in the vicinity of the development scheme. Keeping this in view, no account shall be taken of the effect on value of the scheme of acquisition and development in persuance of which the property is acquired. To take them into consideration in assessing the value of the compulsorily acquired property is to give undue advantage to the owner. This will be a windfall profit which he never expected, or in respect of which he has no legitimate expectations. To allow these advantages to the owner at the cost of the community is to increase speculative business. Therefore, increase or decrease in value due to the development schemes is to be disregarded. The assessment authority will assess the value of the compulsorily acquired property on the assumption that the new scheme had not, and would not come into existence. In Pointe Gourde Quarrying v. Transport Co.,29 Lord MacDermott stated "it is well settled that compensation for the compulsory acquisition of land cannot include an increase in value which is entirely due to the scheme underlying the acquisition". Similarly in Destro and Others v. he Attorney-General 30 it was argued that the owner had no right whatsoever to the development value of the land.

The planning process in modern times has greatly advanced in its technique and utilization. Communities have gone more sensitive to these planning developments. Their participation on the development process has become increasingly important. Under the Town Planning Act (Cap. 13431), such a participation is recognised. Such schemes for development lead to the rise and fall of the social and economic value of the property. 32 To ignore such an increase in the value of the property due to development schemes is, therefore, unjustified. For example, suppose after acquiring the plot of $\mathrm{A}$ under a scheme, he is paid compensation without regard to the scheme for which A's plot is acquired.33 After the scheme is put into operation, it will naturally increase the value of similar plots in the vicinity. If after a time those plots are acquired or even sold in the open market, the advantages of the development scheme will affect their value. One can argue that the property owners in the vicinity of the development scheme have waited long to realise the effect of the development scheme on their property; it is also to be remembered that the person whose property is compulsorily acquired is forced out of the property and never got a chance to realise the effect of the

28 The Land Acquisition Act, Cap. 295.

29 [1947] A.C. 565.

30 [1980] K.L.R. 77 at p. 86.

31 Section 9(2).

32 Collector v. Heptulla and Others [1968] E.A. 555.

33 Destro and Others v. The Attomey-General [1980] K.L.R. 77. 
development scheme. To deny the windfall profits is, therefore, unjustified. The innocent owner should not lose due to the uncertainty of delay in the operation of the development scheme. After all, all businesses have their life in speculation. Speculation is the life-blood of almost all businesses. Is insurance business not a speculative business? Speculation is a part of life, it is a trick of all trades and businesses. The principle laid down in Pointe Gourde's 34 case is not of any value in business transactions. At the most what the state should do is to specify the period, that is limit the period, up which the effect of new development schemes would be considered in calculating compensation for a compulsorily acquired property.

Still on the windfall and speculative business, it is not only the private person who speculates; the government agencies also speculate, whether from a public-use motive or some other motive. In Destro and Others v. The Attomey-General35 it was the speculative business that compelled the government to acquire property because a private businessman was entering into the speculative business to deal with the land. The Government, in fact, had not allocated funds for the purchase of the land, but it wanted to make compulsory purchase in order to avoid extra cost that might be incurred in the future. Even for the development of the compulsorily acquired property, the government wanted to keep the land in reserve, in case international financial agencies offered development funds. Again, under the Local Government Act36 (Cap. 165), the Minister is authorised to acquire private property for public use. He is also authorised to change the use for which property is acquired and sell it. Does this not give the impression that such a power can be used for the speculative purpose of making a profit for the state?

In assessing the compensation for compulsorily acquired private property, no allowance is to be made because the acquisition is compulsory. Nor is any allowance to be made to the former owner, because the private property is urgently required by the state. The unwillingness of the owner in parting with his property does not affect compensation. 37 The compensation is not assessed on any of these subjective factors but on the basis of its market value, in the strict financial sense of the value that would be realised in the open market. The power of the state to acquire the property of its inhabitants is its privilege. For the exercise of this privilege, it is not conceivable that the state should seek the consent of its inhabitants. Therefore, any increase or decrease in the compensation due to the urgency in acquisition or the suitability of the private property acquired to the scheme of the

34 [1947] A.C. 565.

35 [1980] K.L.R. 77.

36 Section 144.

37 The Land Acquisition Act, Cap. 295, Schedule, Section 3(a) and (b). 
acquiring authority, is to be disregarded. In Vyricherla v. Revenue Officer, Vizagapatam ${ }^{38}$ the court held:

The disinclination of the vendor to part with his land and the urgent necessity of the purchaser to buy must alike be disregarded. Neither must be considered as acting under compulsion.

In fact, this rule has no counterpart in the normal valuation process in the open market. The state's power to acquire the property of its inhabitants for public use follows from its sovereign authority, the principle of eminent domain.

The value of the property is to be taken to be its value if sold by a willing seller in the open market. The special suitability becomes nugatory if the special purpose can only be attained in persuance of special statutory powers. Again special suitability is redundant if there is no open market, apart from the special needs of a particular buyer. An increase in the value of the property which the owner makes by making extra improvements on the property to be acquired, with the view to increase the amount of compensation, is also to be disregarded. Section 3(f) of Land Acquisition Act, Schedule39:

In determining the amount of compensation to be awarded for land acquired under this Act, the following matters shall not be taken into consideration - any outlay on additions or improvements to the land, incurred after the date of publication in the Gazette of the notice of intention to acquire the land, unless the additions or improvements were necessary for the maintenance of any building in a proper state of repair.

This rule is to prevent fraud by the owner on the acquiring authority. The owner is restricted to making improvements on the property for which notice is given, where the improvements are necessary to keep the property from disintegrating up to the time of taking of actual possession by the acquiring authority. Any unnecessary improvement to increase the amount of compensation is to be ignored. In fact, the rule is in consonance with common sense and business practices. After equitable interest is created, the owner becomes a trustee for the buyer and hence is under obligation to protect the property. But any increase in value due to the use of the property that can be restrained by the court or is contrary to law is also disregarded. 40 Therefore, the restrictions attached to the property or the restrictions subject to which the vendor holds the property form part of the assessing

38 [1939] A.C. 302.

39 Cap. 295.

40 Institute of Blessed Virgin Mary, Kenya (registered trustees) v. The Commissioner of Lands [1980] K.L.R. 5. 
process. ${ }^{41}$ Their consequences on the property cannot be ignored. This in turn involves an assessment of the type of development that would be permissible within the confines of the planning laws in existence. If the value of the land is enhanced by the likelihood of obtaining planning permission for some valuable use, this can be taken into consideration since it would affect market value. Therefore, the best possible use of the acquired property should be a factor in determining compensation. The possible developments should be taken into account in assessing compensation. What is potentially the best use, of the compulsorily acquired property, should determine the amount of compensation. The Owner should be compensated for unrealised development value in land.

The existing use of the compulsorily acquired property is what the owner is passing to the acquiring authority. But the assessment of compensation on the present existing use does not take into account the owner's right to development. In Destro and Others v. The Attorney-General 42 the Commissioner of Lands advised his senior valuation officer to assess the value of the land on the basis of agricultural use which was the existing use of the land to be acquired. It was also stated in one of the letters to the owner that "the Government will only pay the agricultural value of the land plus a small element for its potential other use".43

But no buyer will buy property in the open market without first checking its potential for development. Property is rarely bought at its face value. Business interests and trade practices in property transactions always scrutinise and think of possible improvements on the existing use of the property before concluding transactions. It is only after such a scrutiny that the value of property is assessed in the open market. Thus, if the Constitution of Kenya refers to market value then all those factors which affect market assessment ought to be taken into account in assessing the compensation for the compulsorily acquired property. Business practice will take into account the best use of the property, and its potential for development, over and above its existing use.

Potential development of the property is, in principle, the right of the owner. Under the Constitution no property right can be alienated without compensation, provided the right can be realised within the bounds of the valid law. It is therefore vital, in assessing market value, to take into account the best use of the property acquired. This is most important in cases where property is not being put to its most profitable use at the time of acquisition. The assessment should be based not on developments that the government can make on the property, but the developments which a private owner can make. Owners' options in this

41 Collector v. Heptulla and Others [1968] E.A. 555. Corrie v. MacDermott [1914] A.C. 1956.

42 [1980] K.L.R. 80.

43 Ibid. 
regard, are limited as compared to those of the state. In fact, it is futile to compare a private owner's use of the property with the resources of the state.

\section{Conclusion}

In assessing compensation the state, however, has provided the assessing authorities and the courts with legislation laying down goveming rules. Notwithstanding the efforts of parliament to remove the uncertainty of compensation by providing guidelines, it still results in many inequities. This is particularly true in recent times, due to social development schemes. The enactment is not sufficiently comprehensive to ensure objectivity. Since full compensation is guaranteed by the Constitution, the rules for assessing compensation ought to be fair and comprehensive enough to meet the ends of social justice, ends that emanate from the concept of full compensation. The legislation laying down rules for assessing compensation are too narrow in scope. With whatever good intentions the parliament passed the guidelines for assessing compensation, so as to meet the constitutional requirement of full compensation, the new factors arising from development schemes have belied those good intentions. The time has come for action, either by the courts to provide a different interpretation to these rules in the light of new developments, or by parliament to amend the rules in the light of new social development schemes. 


\section{Human Rights as a Resource - The Nigerian Experience}

\section{By M. Adekunle Owoade}

Rather than focussing on the international law dimensions of human rights with respect to Nigeria, the article turns to the development processes of human rights within the framework of constitutional history and the Nigerian socio-legal order. The legal developments in Nigeria are discussed on the basis of a wide definition of human and fundamental rights and in the context of the doctrine of natural rights and the philosophy of natural law.

Under both the military and the civil govemment the socio-legal development in Nigeria was characterized by the conflict between the guarantee of civil rights and the need for action with respec to the implementation of social and economic rights. In more general terms, this conflict does not promise a bright future for the promotion and protection of human rights in African states in the light of their past experiences.

The Effect of Modernization on Acquisition of Property and the Rules of Compensation - A Kenyan Case

\section{By R. S. Bhalla}

The constitution of Kenya provides that the state can impose restrictions on the enjoyment and use of property in certain circumstances. If necessary in the wider interest of the community, it can even deprive a person of his private property paying him compensation.

This article is restricted to this aspect of compensation. It examines the rules relating to compensation as provided for by the Land Acquisition Act, Cap. 295. Market value, as a basis for compensation, is only partially effective in restoring the owner's financial position. The main stress in this essay is on the need to compensate the individual to the nearest point of his self-satisfaction. 